FIU Law Review

Spring 2010

\title{
Taking One for the Team: The Persistent Abuse of Eminent Domain in Sports Stadium Construction
}

david Mark

Follow this and additional works at: https://ecollections.law.fiu.edu/lawreview

Part of the Other Law Commons

Online ISSN: 2643-7759

\section{Recommended Citation}

david Mark, Taking One for the Team: The Persistent Abuse of Eminent Domain in Sports Stadium Construction, 5 FIU L. Rev. 781 (2010).

DOI: https://dx.doi.org/10.25148/lawrev.5.2.22

This Comment is brought to you for free and open access by eCollections. It has been accepted for inclusion in FIU Law Review by an authorized editor of eCollections. For more information, please contact lisdavis@fiu.edu. 


\title{
Taking One for the Team: The Persistent Abuse of Eminent Domain in Sports Stadium Construction
}

David Mark*

\begin{abstract}
"Possessing property, and having it protected, is one of the natural, inherent, and unalienable rights of man.",

- Justice William Patterson
\end{abstract}

\section{INTRODUCTION}

Take a moment, and imagine this scenario: You are living in a home that you have resided in for your entire life, one that you hold so close to your heart that you cannot fathom the idea of ever relocating. You have been brought up in this home, have raised your own family in this home, and have a lifetime of memories in this home that you would like to ultimately retire and spend the rest of your life in. You have made improvements to the home over the years that have appreciated its financial value, and you pride yourself on the aesthetic enhancements. Your blood, sweat, and tears have literally been placed into this home that has given you continuous comfort, protection, and privacy. Furthermore, you have built relationships with your neighbors and, together with them, have a vested interest in the community you live in, along with its development and wellbeing.

You arrive home one day, a day which was like any other, where you pick up your children from school after work, and had plans of cooking dinner for the family and enjoying a relaxing evening. As you park the car, you notice a piece of paper taped to your front door. As you approach the door, from a distance you see in big letters the word "NOTICE." You read the rest of the paper, and nearly pass out from shock, as you have just been

\footnotetext{
David Mark is a 2010 graduate of Florida International University College of Law. He has a B.A. in Business Administration from the University of Florida and an M.B.A. from Florida Atlantic University. David served as the FIU Law Review's Managing Editor for 2009-10 and led the efforts in organizing the Labor Law Symposium. He would like to thank Professor Howard Wasserman for his valuable advice on the article's topic, as well as Sandra Friedrich and his parents for all of their love and support.

Vanhorne's Lessee v. Dorrance, 2 U.S. 304, 310 (1795).
} 
notified that your home will be taken from you and demolished. Apparently, your local municipality believes that another property has the possibility of making better use of the land your home sits on, and is now using your state's power of eminent domain in order to make this business decision come to fruition.

After receiving the mandatory evacuation from this place you've called home for so many years, you receive word that the reason why your home has been taken from you is so a professional sports team can build a new stadium in which it could play its games; that the home that you have resided in, and put so much of your time, money, and energy in, is being taken from you so that basketball players, or football players, or baseball players, individuals who make millions of dollars a year, playing for owners who make even more than that, can have a new home where yours used to stand. Unbelievably, a team that moves into one of these new sports facilities may only play eight games there over the entire year. To make matters even worse, the municipality about to take your home from you is not even offering you enough money to pay off your current mortgage.

How could a story like the one above actually occur in this country where we have land and property at the top of our lists of things we value the most? One author captured the essence of what property means to individuals in the United States when he stated that "Americans are serious about the sanctity of private property because they understand that it is not only inseparable from liberty but also the foundation of prosperity." Unfortunately, the story above is not a fictitious tale, and is indeed a reality on a routine basis. The government uses the power of eminent domain to take private property from individuals, and although this practice is authorized by the United States Constitution, its lines are often crossed.

This article will discuss eminent domain and its use when condemning land for professional sports facilities, and argue that there needs to be a bright-line rule for what the Court constitutes a "public use." For a professional team to acquire property through the government's power of eminent domain, it is crucial for the future of property rights that the team demonstrate a legitimate public use. Part II will discuss the history of eminent domain and the power that the U.S. Constitution grants to the government to take such action. Part III will then look at key eminent domain cases that courts have decided, specifically Kelo v. City of New London, ${ }^{3}$ and examine the multiple views that they have taken regarding the issue. Although these landmark cases do not involve the construction of professional sports

\footnotetext{
2 Nicole Gelinas, They're Taking Away Your Property for What?, CiTY J., Autumn 2005, available at http://www.city-journal.org/html/15_4_eminent_domain.html.

3 Kelo v. City of New London, 545 U.S. 469 (2005).
} 
venues, they apply to all situations where private property may be taken via eminent domain. Part IV will examine state and federal responses to Kelo, ${ }^{4}$ a case which this paper argues overly broadened the definition of what exactly constitutes a "public use" for the lawful execution of eminent domain. Part $\mathrm{V}$ will examine the boom in stadium construction over the past twenty years and the lack of public and economic benefits that cities and states receive from such projects. Part VI will discuss the implications for landowners and how the Supreme Court should establish a bright-line rule for determining whether a taking constitutes a public use, and begin to use a heightened standard of scrutiny in any case where the government chooses to exercise its eminent domain power for the purpose of giving the land to another private party. Finally, Part VII will delve into whether sports stadiums should ever be considered a "public use."

\section{HISTORY OF EMINENT DOMAIN}

"At the very beginning of our nation, Americans decided that the enjoyment of our property was among the most important rights possessed by citizens." Our founding fathers clearly laid out the importance of property ownership in a free society by providing in the Declaration of Independence the common goal of "life, liberty, and the pursuit of happiness.", In his Second Treatise of Government, philosopher John Locke acknowledged that the very protection of property rights is the primary reason for creating a government. ${ }^{7}$ However, abuses of the eminent domain power threatening these rights continue to persist in the United States. Eminent domain is defined as:

the right or power to take private property for public use; it is the right of the sovereign, or of those to whom the power has been delegated, to condemn private property for public use and to appropriate the ownership and possession thereof for such use upon paying the owner a due compensation. $^{8}$

Id.

Christopher J. Duerksen \& Richard J. Roddewig, Takings Law, In Plain English, http://www.commerce.wa.gov/_cted/documents/ID_1090_Publications.htm (last visited Aug. 15, 2010).

6 The DeClaration of INDEPENDENCE para. 2 (U.S. 1776).

7 Carol J. Miller \& Stanley A. Leasure, Post-Kelo Determination of Public Use and Eminent Domain in Economic Development Under Arkansas Law, 59 ARK. L. REV. 43, 45 (2006) ("The great and chief end ... of men's uniting into commonwealths, and putting themselves under government, is the preservation of their property. ...").

$8 \quad 29$ C.J.S. Eminent Domain $§ 1$ (2007). 
The concept of eminent domain dates back to biblical times and its power was used by the ancient Romans. ${ }^{9}$ In 1789, the French recognized the power of eminent domain and the requirement of just compensation in the French Declaration of the Rights of Man and of the Citizen, which stated, "[P]roperty being an inviolable and sacred right no one can be deprived of it, unless the public necessity plainly demands it, and upon condition of a just and previous indemnity." ${ }^{, 10}$ The eminent domain power that the United States recognizes today derives from seventeenth and eigtheenth century legal tradition that prohibited the King from taking a subject's property except by a duly enacted law of the land and with full indemnification. ${ }^{11}$ Within the Fifth Amendment of the U.S. Constitution the "takings" clause sets forth that "nor shall private property be taken for public use, without just compensation." 12

The Due Process Clause of the Fourteenth Amendment makes the takings clause applicable to the states. ${ }^{13}$ Breaking the "takings" clause down, we are left with two requirements the government must meet in order to enforce eminent domain: 1) The government can only take private property for "public" use; and 2) the government must pay for it. The "public" use requirement, as this paper will discuss, has been broadened to a level that the country's Founding Fathers never intended it to be. The "just compensation" requirement ensures that the federal government, as well as any state, city, or government authority pays an owner any time the owner's property is taken for public use, in an effort to ease the financial burden incurred by the owner for the benefit of the public. ${ }^{14}$ However, since no precise formula exists for determining what just compensation is, many people are left undercompensated for the value of their property taken, leading to frequent lawsuits. ${ }^{15}$

In the United States throughout the nineteenth and twentieth centuries, the federal and local governments primarily allowed eminent domain to be

9 West's ENCYClOPEDIA OF AMERICAN LAW 227 (1st ed. 1998). "King Ahab of Samaria offered Naboth compensation for Naboth's vineyard." Id.

10 Id.

11 Duerksen \& Roddewig, supra note 5.

12 U.S. CONST. amend. IV, $\S 5$.

13 WEST's ENCYCLOPEDIA OF AMERICAN LAW, supra note 9, at 227.

14 Id.; see also William Michael Treanor, The Origins and Original Significance of the Just Compensation Clause of the Fifth Amendment, 94 YALE L.J. 694, 712 (1985). Treanor describes James Madison's rationale behind requiring "just compensation" under the 5th Amendment. The requirement, according to Madison, evidences "pride . . . in maintaining the inviolability of property." Not relying on this principle and taking land without "just compensation" would dishonor the government's commitment to personal freedom. Id.

15 WEST's ENCYCLOPEDIA OF AMERICAN LAW, supra note 9, at 228 
enforced in situations that truly were for legitimate public uses. ${ }^{16}$ These public uses included means which furthered American society, such as the building of roads, bridges, airports, hospitals, and public buildings. ${ }^{17}$ Courts would eventually begin to expand the eminent domain power by allowing certain private companies to take property, such as railroads to build tracks, and public utilities to install transmission lines; but even then, these companies were highly regulated. ${ }^{18}$ They had to provide to the public equal access to their facilities. ${ }^{19}$ Thus, it is well settled that the traditional application of eminent domain was to promote public safety, public health, morality, peace and quiet, and law and order. ${ }^{20}$

As time progressed, states began to abuse and take advantage of the eminent domain power by construing the public use requirement more broadly. The public use requirement merged into a broader concept of public purpose, and no longer was it mandatory that the taking qualify as a public use; rather, now the condemned property could be put in the hands of private entities and developers that served to their benefit. As a result, sports team owners are now able to convince politicians that building a multimillion-dollar facility in their cities will bring in enormous revenues, and in turn the politicians have the easy ability to acquire the land needed for construction.

\section{KEY COURT DECISIONS ON EMINENT DOMAIN}

There are a series of eminent domain property cases that have shaped how property rights are decided today. Unfortunately, the last in the series discussed below, Kelo v. City of New London, ${ }^{21}$ has opened the door wide open for private property to be condemned for a wide array of reasons beyond those that were originally deemed to be for a public use.

\section{A. Berman v. Parker: The Expansion of "Public Use"}

In Berman v. Parker, ${ }^{22}$ the Court battled with the constitutionality of the District of Columbia Redevelopment Act of 1945 and the authority granted by this Act for a local agency to take private property and give it to

\footnotetext{
16 The Castle Coalition, History of Eminent Domain and its Abuse, http://www.castlecoalition.org/index.php?option=com_content\&task=view\&id=512 (last visited Aug. $15,2010)$.

17 Id.

$18 \quad I d$.

19 Id.

20 Berman v. Parker, 348 U.S. 26, 32 (1954).

21 Kelo v. City of New London, 545 U.S. 469 (2005).

22 Berman, 348 U.S. at 26.
} 
another private entity. ${ }^{23}$ The purpose of the Act was to acquire, through the power of eminent domain, real property for "the redevelopment of blighted territory in the District of Columbia and the prevention, reduction, or elimination of blighting factors or causes of blight." ${ }^{24}$ The Act had previously been challenged, but the district court held that the Act could stand, as it permitted the Agency to only condemn property for the reasonable necessities of slum clearance and prevention, with the court defining "slum" as the existence of conditions "injurious to the public health, safety, morals and welfare." 25

The petitioner in Berman owned a department store in Area B, one of the areas of land that the Agency deemed for redevelopment. ${ }^{26}$ Challenging the constitutionality of the Act on the grounds that his store was not slum housing, the petitioner argued that it would be taken from him and then put under the management of a private, not a public, agency and redeveloped for private, not public, use. ${ }^{27}$ The petitioner's argument, in essence, was that the Agency would be "taking from one businessman for the benefit of another businessman." ${ }^{28}$ His business did not threaten the public's health or safety, nor did it contribute to the area that the Agency felt was a "slum" and "blighted" area. ${ }^{29}$ The Court, seemingly recognizing and agreeing with the petitioner's claims, asserted "[t]o take for the purpose of ridding the area of slums is one thing; it is quite another, the argument goes, to take a man's property merely to develop a better balanced, more attractive community."

Nevertheless, the Court in Berman held that the Agency's redevelopment plan was reasonable, and that the Agency was permitted to redesign the whole area, rather than remove only the "unsightly" buildings. Addressing the idea of transferring property from one private owner to another, the Court determined that the public end may be served just as well, or even better, through a private enterprise than through a government department. $^{32}$ The Court believed that there were other methods of promoting purposes of community redevelopment projects, besides public ownership.

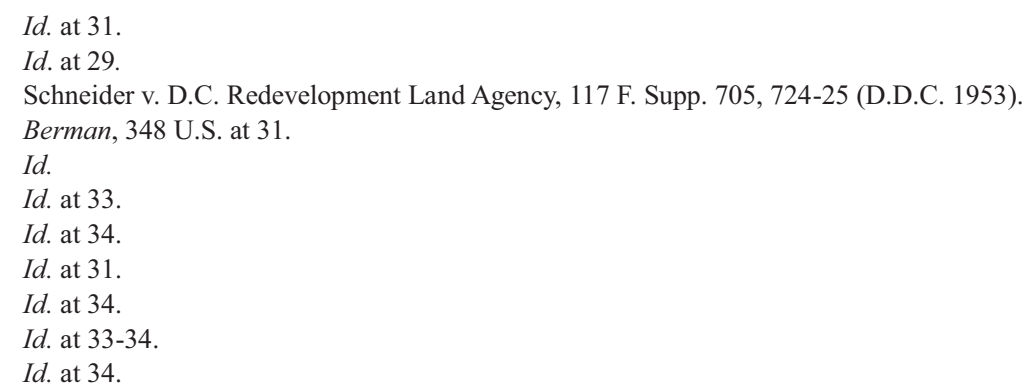


Furthermore, the Court maintained that it is the job of the legislature, not the judiciary, to ensure that public needs are met, and that " $[\mathrm{t}]$ he role of the judiciary in determining whether that power [eminent domain] is being exercised for a public purpose is an extremely narrow one.",

The Court in Berman ignored the rationale of the Fifth Amendment by broadening the scope of "public use," which resulted in less protection of private property from government intrusion. By allowing the property of a private owner to be taken and given to another private entity in order to cure a blighted area, the Court opened the floodgates for future takings that ignore the Fifth Amendment's purpose. This decision, in effect, expanded the definition of "public use" in the takings clause, by equating it with "public benefit."

\section{B. Poletown Neighborhood Council v. City of Detroit: The Abuse Continues}

In Poletown Neighborhood Council v. City of Detroit, ${ }^{35}$ the issue was whether the city of Detroit abused its discretion in determining that the taking of the plaintiffs' property was necessary to complete a project that included the construction of a General Motors Corporation assembly plant. $^{36}$ In making its determination, the court looked to see if the City's use of eminent domain constituted a taking of private property for private use in violation of Article 10, Section 2, of Michigan's Constitution, which had been interpreted to restrict eminent domain to situations that further a public use or purpose. ${ }^{37}$ The plaintiffs included a neighborhood association, as well as several individual residents who resided in the area where the condemnation was to take place. ${ }^{38}$ In order to bring in the General Motors plant, Detroit would condemn a total of "1400 homes, 144 businesses, sixteen churches, two schools, and a hospital." 39 Together, the plaintiffs urged the court to recognize that a difference exists between public "use" and public "purpose." 40 The court was quick to point out that the two terms had been used interchangeably throughout Michigan statutes and decisions, and that the court had never narrowed the scope of the "public use" definition.

\footnotetext{
Id. at 32 .

Poletown Neighborhood Council v. City of Detroit, 410 Mich. 616 (1981).

Id. at 628 .

Id. at 629; see also MiCH. CONST., art. X, § 2 ("[Private] property shall not be taken for public use without just compensation therefor being first made or secured in a manner prescribed by law.").

38 Poletown, 401 Mich. at 628.

39 Jeanie Wylie, Poletown: Community Betrayed 55 (1990).

40 Poletown Neighborhood Council, 410 Mich. at 629-30.
}

41 Id. at 630. 
In fact, the court severely broadened the requirement of "public use" by stating that "[a] public use changes with changing conditions of society.",

The plaintiff's main contention was that the City was ignoring the constitutional restraints on eminent domain, and using the power to condemn one person's private property to convey it to another private person or entity in order to bolster the economy. ${ }^{43}$ This conveyance, the plaintiffs argued, "is really a taking for private use and not a public use because General Motors is the primary beneficiary of the condemnation." according to the plaintiffs, was only incidental to the primary private benefit of profits that General Motors would raise. ${ }^{45}$ The defendant's argument was that with its facility would come economic uprising, increased tax revenue, and the creation of many jobs, and that the conveyance of the property to a private entity does not mean that the public purpose is the priority. ${ }^{46}$

In Michigan's Economic Development Corporations Act, it was stated that one of the main objectives to provide for the general health, safety, and welfare, was to alleviate unemployment by assisting industry. ${ }^{47}$ As the Supreme Court did in Berman v. Parker, the court in this case deferred to the legislature and its decision that the governmental action taken by the city met a public need (to rejuvenate the local economy) and served an essential public purpose. ${ }^{48}$

Although Poletown was not heard in a federal court, this case essentially set the precedent throughout the country, for widespread abuse of the power of eminent domain for private development. Yet the outcome that resulted from the General Motor plant's construction should have been a warning for future decisions on eminent domain issues when the taking of private property for private development is premised on the idea that a plan will cure blight and improve an economy. Detroit's \$200 million investment to destroy the "blighted" Poletown neighborhood never paid off. ${ }^{49}$ General Motors did not even meet half of its promised creation of 6,000 new jobs. ${ }^{50}$ The 600 businesses that were taken so that GM could move in had likely employed more individuals than GM ever did in its new plant. ${ }^{51}$

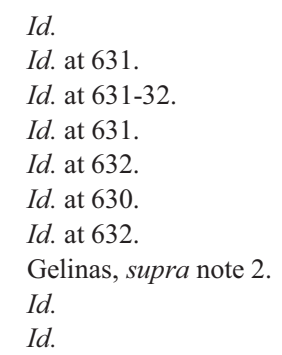


C. Hawaii Housing Authority v. Midkiff: "Public Purpose" is Sufficient

The petitioner in Hawaii Housing Authority v. Midkiff $f^{2}$ brought suit to challenge the Hawaii Land Reform Act, which allowed for the condemning of private residential tracts that were then sold to private, individual buyers. $^{53}$ The Act permitted lessees who lived on residential lots within tracts of at least five acres in size to ask the Hawaii Housing Authority to condemn the property on which they lived. ${ }^{54}$

The Court held that a redistribution of fees simple to improve a sloping economy caused by a land oligopoly is a rational exercise of the eminent domain power and therefore satisfies a public use. ${ }^{55}$ The Court looked at the precedent established in Berman, ${ }^{56}$ and found that it was a legitimate public purpose for the statute to target a suffering economy that was caused by concentrated land ownership. ${ }^{57}$ In rejecting the plaintiff's contention that the transfer of property to private beneficiaries was unlawful, the Court noted that it "long ago rejected any literal requirement that condemned property be put into use for the general public." 58

Midkiff redefined the takings clause, as it made the transition of "public use" to "public purpose" in determining whether a use of eminent domain power is constitutional.

D. County of Wayne v. Hathcock: "Public Use" Does Not Mean "Public Purpose"

In County of Wayne v. Hathcock, ${ }^{59}$ Wayne County attempted to use the power of eminent domain to condemn the defendant's private property so that it could construct a 1,300-acre business and technology park. ${ }^{60}$ The plaintiff, as the City of Detroit had done in Poletown, claimed that the park's purpose was to "reinvigorate the struggling economy," by attracting businesses. $^{61}$ The defendant argued that this exercise of eminent domain would be unconstitutional under Article 10 of the 1963 Michigan Constitution (requiring any condemnation of private property to occur only if it

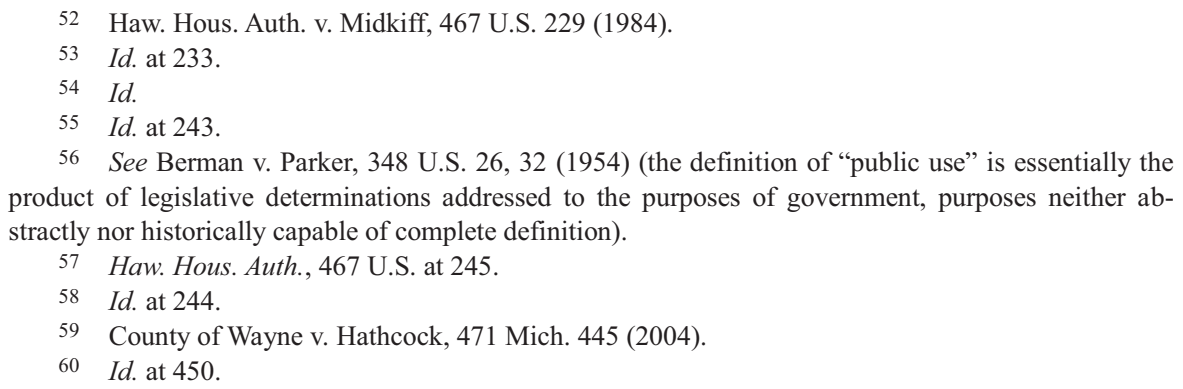


advances a "public use"), and is not authorized in any state statute. ${ }^{62}$ Thus, once again, the issue facing the Michigan court was whether Poletown's "public purpose" test was constitutional under Article 10, Section 2 of the Michigan Constitution, which states that "private property shall not be taken for public use without just compensation.",63

The court in Hathcock set out three characteristics (all of which were originally discussed in Poletown's dissent), where a constitutional public use exists when a condemnation of private property takes place. ${ }^{64}$ First, "[t]he exercise of eminent domain for private corporations has been limited to those enterprises generating public benefits whose very existence depends on the use of land that can be assembled only by the coordination central government alone is capable of achieving." ${ }^{65}$ Examples include instrumentalities of commerce, such as when a private property is condemned to build a highway. ${ }^{66}$ The second characteristic of a constitutional public use from a private property condemnation, the court pointed out, is when the private entity who receives the property "remains accountable to the public in its use of that property." private pipeline company had met the public use requirement when the company promised to conduct its business within intrastate commerce, used the pipeline according to how the Michigan Public Service Commission directed it to, and would be under the state's direction and control to enforce these obligations. ${ }^{68}$ Thus, the public retained a measure of control over the property. ${ }^{69}$ Finally, the transfer of condemned property to a private entity is constitutional where the property that is condemned is chosen because of "facts of independent public significance," rather than to the benefits and interests of the private entity receiving the property. ${ }^{70}$ In other words, if a condemnation of blighted property occurs, and the property is resold to private individuals, a public use occurs if the controlling purpose in condemning the properties is to remove them for the public's well-

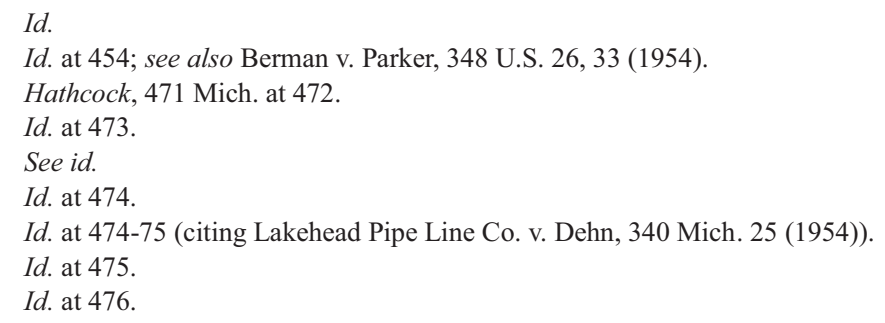


being. ${ }^{71}$ This holds true despite the fact that the condemned properties would be put to private use.

After years of the courts giving a broad definition to the "public use" requirement of eminent domain by equating it with "public purpose," the court in Hathcock narrowed this view and applied the three-part checklist above, finding the County of Wayne's condemnations to be unconstitutional because the condemnation did not fall in line with any of the three elements. ${ }^{73}$ The park did not require the exercise of eminent domain, as its existence did not depend on the use of land that could only be acquired through the government's power. ${ }^{74}$ Next, the park was not going to be under the public's oversight and control to ensure that the property would continue to promote the health of the local economy; the primary result of the park would be for the private entity's own financial benefit. ${ }^{75}$ Furthermore, "there [was] nothing about the act of condemning defendants' properties that serve[d] the public good in this case..76 The court did not find any facts of independent public significance that would justify the condemnation, and the benefits that were cited by the County of Wayne would only arise after the lands would be put to private use.

The court's decision in Hathcock addressed the question as to whether there is a distinction between "public use" and "public purpose," an issue that the court felt was avoided in Poletown. ${ }^{78}$ In doing so, the court determined that there indeed is a clear distinction between the two concepts that had been equated in Poletown and previous cases since. ${ }^{79}$

\section{E. Kelo v. City of New London: The Perpetuation of the Broad "Public Use" Reading}

Just as it had seemed as though the courts were reverting back to the original meaning of the takings clause after County of Wayne v. Hathcock was decided, as well as other cases that narrowed the "public use" definition, ${ }^{80}$ Kelo v. City of New London ${ }^{81}$ was heard by the Supreme Court in a

71 Id. at 475-76 (citing In re Slum Clearance, 331 Mich. 714 (1951), where the Court held that Detroit's condemnation of blighted housing and its subsequent resale of those properties to private individuals was constitutional since it was to advance public health and safety).

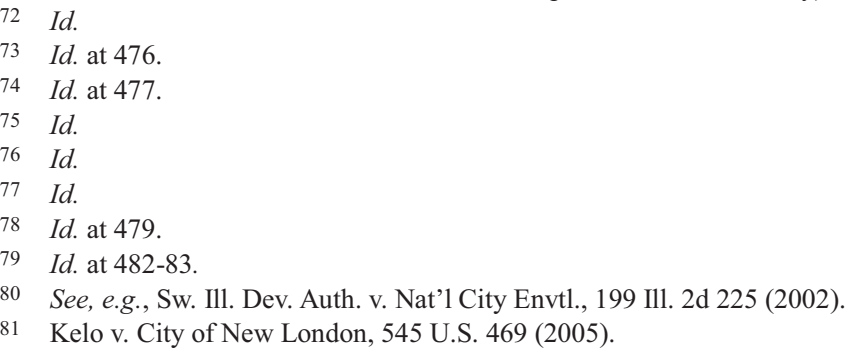


landmark case that has had the effect of being arguably the most important property rights case in recent memory.

In Kelo, New London was a city that was suffering with a poor economy, declining population, and an unemployment rate that was nearly double that of any other city in Connecticut. ${ }^{82}$ In response to these conditions, state and local officials established the New London Development Corporation (NLDC), a private nonprofit entity, in order to create plans that would revitalize the city. ${ }^{83}$ The NLDC proposed a redevelopment plan that consisted of seven parcels, on which a conference hotel, offices, restaurants, shopping, marinas, a pedestrian riverwalk, U.S. Coast Guard Museum, and approximately eighty new residences would be built. ${ }^{84}$ The plan was intended to capitalize on the arrival of the pharmaceutical company, Pfizer, Inc., which had just announced that it was going to build a $\$ 300$ million research facility on a parcel of land immediately adjacent to the parcels the NLDC planned to redevelop. ${ }^{85}$ The NDLC claimed that the proposed plan would create jobs, generate tax revenue, revitalize the downtown area, and make the city more attractive. ${ }^{86}$

In order for the plan to go through, the city council approved the NLDC's plan and authorized it to acquire property by exercising eminent domain. ${ }^{87}$ There were nine petitioners overall, who owned a total of fifteen different properties on the proposed plan's land. ${ }^{88}$ Lead plaintiff Susette Kelo had lived in her waterfront home since 1997, and had made "extensive improvements" to her property since that time. ${ }^{89}$ Another plaintiff had lived in her home for her entire life, since $1918 .^{90}$ Her husband had lived in the home from the time they were married sixty years earlier. ${ }^{91}$ They claimed that the taking of their properties would violate the "public use" restriction in the Fifth Amendment's taking clause. ${ }^{92}$

However, the Connecticut Supreme Court, relying on prior broad treatment given to its public use clause, stated that "an economic development plan that the appropriate legislative authority rationally has determined will promote significant municipal economic development, consti-

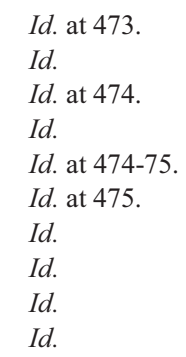


tutes a valid public use for the exercise of the eminent domain power under both the federal and Connecticut constitutions." "93 Thus, the court found that the economic development plan was constitutional and that the NLDC was able to enforce eminent domain since it was not acting for its own primary benefit. $^{94}$ The dissent, however, strongly disagreed with the holding, and declared that a condemnation issue such as this one would have required "the taking authority to establish by clear and convincing evidence that the public benefit anticipated in the economic development agreement [was] reasonably ensured." 95 The issue facing the Supreme Court in Kelo, therefore, was whether the city's decision to exercise eminent domain and take private property for the purpose of economic development satisfied the "public use" requirement of the Fifth Amendment.

The plaintiffs urged the Court to "adopt a new bright-line rule" that establishes that "economic development does not qualify as a public use." The Court responded that "[p]romoting economic development is a traditional and long-accepted function of government." 98 The majority found the statutory language relied upon by the defendant to be valid and constitutional. $^{99}$ In doing so, the Court determined that the use would satisfy the Fifth Amendment's "public use" requirement as long as the plan would serve a public purpose. ${ }^{100}$ The Court noted that "there is no basis for exempting economic development from our traditionally broad understanding of public purpose."

Thus, the Court in Kelo seemed to have determined that the factors that led to its decision were the "comprehensive character" of the city's plan, and the "thorough deliberation that preceded [the plan's] adoption."102 However, as one scholar has pointed out, "there would be no reason to have takings protection at all if governments . . . only acted in the interest of the entire public every time they took land [and] . . . had superior knowledge of

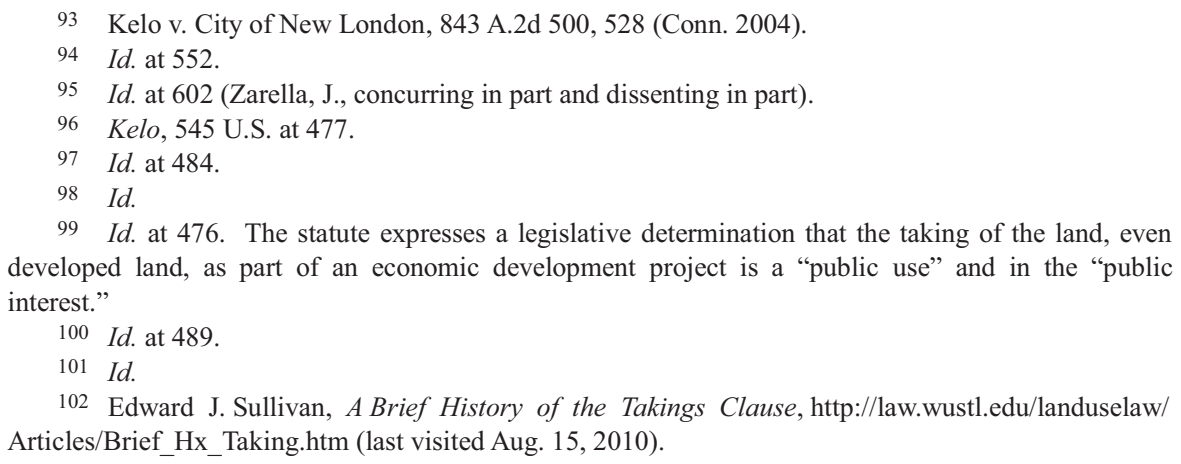
developed land, as part of an economic development project is a "public use" and in the "public

100 Id. at 489.

102 Edward J. Sullivan, A Brief History of the Takings Clause, http://law.wustl.edu/landuselaw/ Articles/Brief_Hx_Taking.htm (last visited Aug. 15, 2010). interest."

101 Id. 
the anticipated consequences of their actions. ..." only perpetuated the dwindling of private property rights by allowing for a broad reading and interpretation of the "public use" requirement.

\section{State AND FEDERAL RESPONSES TO KELO}

There have been some states that have recognized how the floodgates for litigation were opened with the holding in Kelo, and thus have narrowed the public use requirement in order to curb the power of local governments to enforce eminent domain. As the majority in Kelo noted, "[n]othing in our opinion precludes any State from placing further restrictions in its exercise of the takings power." " State of Illinois legislators, for example, are currently reviewing legislation that would require compensation to be about twenty-five to fifty percent higher than the appraised value because many property rights advocates are claiming that the government's power to invoke eminent domain is too easy. ${ }^{105}$ Illinois law currently reads that property must be blighted before the government can take it via eminent domain, yet to these property rights advocates, the definition of "blighted" is too broad. ${ }^{106}$

As protection for homes and businesses after the Kelo decision came down, the Alabama Senate and House unanimously passed a bill preventing local governments from using the power of eminent domain to condemn property for private development. ${ }^{107}$ The State of Delaware wasted no time following the Kelo holding, realizing the dangers that it could lead to, and just one month after signed a bill defining "public use" as allowing for eminent domain to be used only for public buildings, utilities, and roads. ${ }^{108}$ Even before Kelo, Colorado had amended its eminent domain law with the purpose of restricting the use of eminent domain by redevelopment agencies seeking to transfer private property from one private party to another. ${ }^{109}$ The amendment requires that the property targeted for condemnation be blighted or located within a blighted area. ${ }^{110}$ If the property does not meet this requirement, then it must be determined that without such a condemnation proceeding on the particular property, the urban renewal plan

\footnotetext{
103 Richard Epstein, Kelo: An American Original: Of Grubby Particulars and Grand Principles, 8 GREEN BAG 2d 355, 359 (2005).

104 Kelo, 545 U.S. at 489.

105 Justin Morton, States and Eminent Domain: Limiting Public Use, Increasing Compensation, Fall 2005, http://findarticles.com/p/articles/mi_m0JDE/is_4_10/ai_n25120926.

106 Id.

107 Id.

108 Id.

109 H.R. 1203, 64th Gen. Assem., 2d Reg. Sess. (Colo. 2004).

110 Id.
} 
will not be able to be accomplished. ${ }^{111}$ In California, using eminent domain for economic development is only allowed for the redevelopment of blighted areas, which the State considers to be a public use. ${ }^{112}$ California leaves little room for mistake as it clearly sets out in its codes what it considers to be "blighted.", Other states, including Pennsylvania and Missouri, have also taken steps to ensure that the broad public use requirement set out in Kelo is not abused under their authority.

Although these states have taken useful steps in granting the individual property owners who reside within their borders the property rights that were set forth by this country's Founding Fathers, unfortunately many of the laws are not as clear as California's and are poorly drafted to the point that just about any piece of property, including very good homes, can be declared blighted. ${ }^{114}$ Currently, a line separating blighted property from non-blighted property does not exist. After Kelo, it is now up to the states to continue to expand protection to private property holders, and they can begin by establishing clear parameters of what constitutes "blight," for purposes of exercising eminent domain. If not, there will continue to be these interpretational issues that will allow the government to declare a piece of property blighted without any grounds for challenging its decision. For example, the State of Texas has passed a bill that attempts to limit government's eminent domain power by allowing the taking of only property that will be for the purpose of eliminating slum and blight; however, the legislature never set out a clear definition of blight. ${ }^{115}$ A proper definition of "blight" will establish that in order for the property to be condemned for redevelopment through the exercise of eminent domain, the property must

111 Id.

112 See Cal. Health \& SAFETy CODE 33030-33039, available at http://www.leginfo.ca.gov/cgibin/displaycode?section=hsc\&group=33001-34000\&file=33030-33039.

113 Id. $\S 33030$ (defining "blighted area" as an area that is predominantly urbanized . . . and is an area in which conditions set forth [within the statute] are so prevalent and so substantial that it causes a reduction of, or lack of, proper utilization of the area to such an extent that it constitutes a serious physical and economic burden on the community which cannot reasonably be expected to be reversed or alleviated by private enterprise or governmental action, or both, without redevelopment).

114 Pat Beall, Riviera Beach Eminent Domain Case Draws National Spotlight, PALM BEACH POST, Dec. 11, 2005, at A1; see also Alberto B. Lopez, Revisiting Kelo and Eminent Domain's "Summer of Scrutiny”, 59 ALA. L. REV. 561, 594 (2008) (discussing the minimal effectiveness of legislative amendments as "definitions of blight are so vague that they fail to act as a meaningful restraint on the government's power of eminent domain ... the properties that characterize blighted property escape precise definitions").

115 Adrianne Archer, Restricting Kelo: Will Redefining "Blight" in Senate Bill 7 Be the Light at the End of the Tunnel?, 37 ST. MARY's L.J. 795, 844 (2006) (discussing Texas' move in the right direction of eminent domain legislation, but that even more limitations should be included in future amendments to chapter 2206 of the Texas Government Code). 
have a "grave, objective, and identifiable problem.", Defining "blight" in this manner would likely put an end to the ease with which the government can unnecessarily identify a property as one that needs to be redeveloped. ${ }^{117}$

In response to the Court's decision in Kelo, the United States House of Representatives and Senate have both proposed legislation to limit the states' power of eminent domain when the reason for conducting it is socalled "economic development." The Protection of Homes, Small Businesses, and Private Property Act was introduced on June 27, 2005 by Senator John Cornyn. ${ }^{118}$ In support of the Bill, Senator Cornyn cited to the Founders' intent, along with Thomas Jefferson's statement that the protection of such property rights is "the first principle of association, the guarantee to every one of a free exercise of his industry, and the fruits acquired by it." $" 19$ Thus, with the belief that the Court in Kelo failed to properly enforce the Federal Constitution with an effective deletion of the words "for public use," the Bill states that "[t]he power of eminent domain shall be available only for public use," with which the term "public use" "shall not be construed to include economic development." respond to the overly broad eminent domain power that has developed and reestablish the fundamental protections of the Fifth Amendment consistent with its limited powers under the Constitution. ${ }^{121}$ Furthermore, the Bill targets both the federal government, as well as state and local governments. $^{122}$

The same month that the Protection of Homes, Small Business, and Private Property Act was introduced, the House, in a move that seemed to show its disagreement with the Kelo decision, took advantage of Congress's spending power and passed an amendment to an appropriations bill that would deny federal funds to any city or state profit-making project, i.e., a mall or hotel, that took property from individuals through its exercise of eminent domain. ${ }^{123}$ In showing his support for the Act and distaste for the Court's decision in Kelo, the House Majority Leader at the time, Tom

116 Id. at 845.

117 Id. Government has abused the power of eminent domain by having too much leeway to decide what a blighted property consists of. In the past, some properties that have been designated to be "blighted" include homes that have had a one-car garage, one bathroom, or a side yard that was too small.

118 S. 1313, 109th Cong. $§ 1$ (2005), available at http://www.govtrack.us/congress/ bill.xpd?bill=s $109-1313$.

119 Id.

$120 \mathrm{Id}$.

121 Id.

122 Id.

123 Mike Allen \& Charles Babington, House Votes to Undercut High Court on Property: Federal Funds Tied to Eminent Domain, WASH. Post, July 1, 2005, at A1. 
DeLay, stated that "[t]his Congress is not just going to sit by - idly sit by and let an unaccountable judiciary make these kinds of decisions without taking our responsibility and our duty given to us by the Constitution to be a check on the judiciary." ${ }^{24}$ One of the individuals who sponsored the bill, Judiciary Committee Chairman F. James Sensenbrenner Jr., said that the Kelo decision showed that "the majority of the Court had an utter disrespect for private property." ${ }^{125}$

A few months after the bills discussed above were introduced, the Private Property Rights Protection Act was proposed with the goal of preventing any state from receiving federal economic development funds during any fiscal year in which that state exercises its power of eminent domain over property intended to be used for economic development. ${ }^{126}$ The Bill sets forth a definition of "economic development" as "taking private property, without the consent of the owner, and conveying or leasing such property from one private person or entity to another private person or entity for commercial enterprise carried on for profit, or to increase tax revenue, tax base, employment, or general economic health."127 The Bill then proceeds to lay out projects that do meet the standard of "economic development," such as roads, hospitals, airports, military bases, and pipelines - all projects that the power of eminent domain was founded on. ${ }^{128} \mathrm{~A}$ definition of "economic development" as is set out in this Bill is exactly what is needed and what should be followed by the Court when determining if an eminent domain power is constitutional. Enactment of any such bill discussed above would definitely sway state and city legislators away from the idea of eminent domain as the solution to their stadium plans.

\section{THE STADIUM BOOM AND ITS EFFECT ON LANDOWNERS}

Over the last fifteen years, there has been a boom in new stadium construction and renovation of the likes never before seen. Between 1999 and 2003, there were sixty-six major construction and renovation projects in the United States, which cost an estimated $\$ 17.3$ billion. $^{129}$ As of October 2007, sixty-five professional sports teams had either moved into a brand new facility or had made major renovations to their current facilities since

\footnotetext{
124 Id.

125 Id.

126 H.R. 4128, 109th Cong. (2005), available at http://www.govtrack.us/congress/ billtext.xpd?bill=h109-4128.

127 Id.

128 Id.

129 Daniel McGraw, Demolishing Sports Welfare: Two Court Cases Could Mean the End of Publicly Funded Stadium, REASON, May 2005, at 32.
} 
1996. ${ }^{130}$ Since that time, thirteen other professional sports franchises have made plans to complete new stadiums by $2012 .^{131}$

The driving force behind this stadium boom is money. Player salaries and other costs for team owners continue to rise at an alarming rate. ${ }^{132}$ In response, the owners, looking for better ways to increase revenues and profits that they do not have access to in their current venues, pursue new facilities for their teams that will allow for financial opportunities stemming from additional sponsorships, licensing deals, and sales from luxury suites and other premium seating. ${ }^{133}$ This is when the owners go to their city officials, local politicians, and potential investors and offer them a list of socalled advantages that will be brought to the city if it so chooses to build them a new facility. ${ }^{134}$ Should the city turn down such a request, it is common for an owner to threaten relocation, knowing full well that that there are many cities throughout the country that would love the "prestige" that comes with having its own sports franchise. ${ }^{135}$ Hence, the cities face pressure to keep their teams around and take measures, such as executing their powers of eminent domain, in order to do so.

There was a time when the construction of sports facilities, for the use by professional sports teams, was a purely private venture. ${ }^{136}$ The team owners would purchase the land and privately fund their stadiums. ${ }^{137}$ The owners would have to make do with the land that they bought, as their stadiums had to "fit on a particular piece of urban land, often within a set of city streets and having to accommodate many neighbors." "138 For example, the right-field wall of old League Park in Cleveland was a mere 290 feet from home plate, as "the owners of a saloon and two houses refused to sell their land." 139 This was a time in which cities, local governments, and the politicians within them did not abuse the power of eminent domain by taking an individual's private property for the purpose of transferring it to

130 John R. Middleton, Jr., Scott L. Walker \& Matthew Savare, Stadia Mania: The Business, Civic and Legal Issues of New Stadium Construction Part One, http://www.metrocorpcounsel.com/ current.php?artType=view\&artMonth=February\&artYear=2008\&EntryNo=7843.

131 Id.

132 Id.

133 Id.

134 Id.

135 For example, in 1996, Jeffrey Loria, owner of Major League Baseball's Florida Marlins, threatened to relocate after the collapse of a deal to build a new stadium. See Loria Renews Threat to Move Marlins, ASSOCIATED PRESS, available at http://sports.espn.go.com/mlb/news/story?id=2405332 (last updated Apr. 11, 2006).

136 Raymond J. Keating, New Stadiums Hit Property Rights, NewSDAY (New YoRK), May 21, 2007, at A39.

137 Middleton, Walker \& Savare, supra note 130.

138 Id.

139 Id. 
another for private use. ${ }^{140}$ Today, we no longer see this protection of the takings clause, as governments "muscle" homeowners and small businesses off their properties with claims of "public use" and "public purpose," when in reality it is the private entities receiving the land who are getting enriched at the public's expense. ${ }^{141}$

The costs associated with a professional sports team, including the ever-increasing player salaries mentioned above, mean that the stadium boom will not slow down any time soon. Therefore, it is evident that property disputes will continue to occur as the government takes private property at will for the building of these facilities.

\section{A. What Economic Impact Do Sports Facilities Really Provide?}

Raymond J. Keating, chief economist for the Washington-based Small Business \& Entrepreneurship Council and an expert on sports facility financing, recently said, "[t]here is no dispute in the economic community about who gets the primary benefit from the subsidy. Obviously the clear benefits go to the team owners and the players." "I42 In fact, polls and testimony show that just about the whole country is against eminent domain for private gain, and it is clear that its main supporters are those who benefit from it: politicians, developers, and planners.

During a recent congressional hearing regarding the financing of professional sports stadiums, held by the Subcommittee on Domestic Policy of the Committee on Oversight and Government Reform, Arthur Rolnick, Senior Vice President and Research Director of the Federal Reserve Bank of Minneapolis, replied to the idea of eminent domain by saying that "it's an abuse to use eminent domain to take from one private company and give to another. Eminent domain was strictly supposed to be used . . . to build a public institution, a library, a school, not a sports stadium." 144 In reality, the public benefits promised by sports team owners and government officials

140 Id.

141 Id. In 1991, former President George W. Bush, then owner of Major League Baseball's Texas Rangers, convinced local voters to approve a tax that helped build a new \$191 million stadium. Eminent domain was claimed based on claims of "public use," the owners who lost their land were "lowballed," Bush turned his $\$ 600,000$ investment into $\$ 15$ million when the team was sold in 1999 , and the City of Arlington saw little economic benefit. McGraw, supra note 129.

142 McGraw, supra note 129.

143 Report: Eminent Domain Could Hinder Development, N. CounTy GaZETTE, Feb. 4, 2007, available at http://www.northcountrygazette.org/articles/2007/020407HinderDevelopment.html.

144 Atlantic Yards Report, http://atlanticyardsreport.blogspot.com/ (July 4, 2008, 04:01 EST). 
rarely materialize. ${ }^{145}$ Such initiatives often take advantage of taxpayers' money and become a public burden rather than a public benefit. ${ }^{146}$

It has been estimated that half of the new professional sports facilities built over the last fifteen years were constructed after the eminent domain power was enforced. ${ }^{147}$ Eminent domain allows team owners to capitalize on the acquisition of the land since they do not have to dig deep into their own pockets to purchase the property, and even when the power is not invoked, the owners know that it could always be used as a last resort if the "teams encounter[] any stubborn landowners." 148 Owners frequently threaten that if a new stadium is not built for them, they will relocate their teams to cities that are willing to do so. ${ }^{149}$ The owners, cities, and advocates for a new stadium attempt to back up their desires with impact studies, which are often skewed in their favor by showing large economic benefits. $^{150}$

Similar to stadiums, there has been a recent construction boom of convention centers, where government-sponsored economic studies are used in support of the projects. ${ }^{151}$ An urban policy expert who recently analyzed thirty of these studies that supported convention center construction found them "consistently flawed and misleading." in his Kelo opinion, where he stated that the New London Development Corporation "has carefully formulated an economic development plan that it believes will provide appreciable benefits to the community,"153 owners are only having to show that a study has been done that shows that the potential for benefits are projected and courts are not required to make a factual determination that a plan will meet any of its estimated goals. ${ }^{154}$ The dissenters in Kelo agreed that the redevelopment plan was intended to serve a valid public use; however, they believed the takings to be unconstitutional because the defendant failed to show "clear and convincing evidence" that the economic benefits of the plan would be realized by the community. ${ }^{155}$

Despite the beliefs of local officials about the potential benefits that a stadium can bring to an economy, there is a majority of economists who

145 Steven Malanga, Eminently Dumb Eminent Domain, L.A. TiMES, July 20, 2005, at B13.

146 Id.

147 McGraw, supra note 129, at 32.

$148 I d$.

149 Dennis Coates \& Brad Humphreys, The Stadium Gambit and Local Economic Development, http://www.cato.org/pubs/regulation/regv23n2/coates.pdf.

150 McGraw, supra note 129, at 17.

151 Malanga, supra note 145, at B13.

152 Id.

153 See Kelo v. City of New London, 545 U.S. 469, 483 (2005).

154 Id. at 488.

155 Id. at 477. 
believes that this idea is fictitious. ${ }^{156}$ The people footing the bill for these new stadiums, the individual taxpayers, are promised that the stadiums and teams coming to play in them will bring thousands of new jobs, an increase in tax revenues and income for their city, and an overall feeling of greater civic pride and image that is associated with living in the same city as a professional sports franchise. ${ }^{157}$

\section{B. Flawed Economic Studies}

There have been many empirical studies conducted which show that the revenues brought in by having a professional sports franchise and stadium are modest, as the number of fans who attend from out of town are minimal and would have traveled to the city regardless of a team and fancy stadium being there. ${ }^{158}$ The spending at the stadiums produces a multiplier effect. $^{159}$ Many of the large money-makers in professional sports do not even live in the town they play in, and thus spend their millions, and pay taxes, in other cities and states. ${ }^{160}$ Furthermore, a "substitution effect" occurs, where money spent at the stadium is only replacing the money spent on another activity; no new revenues are actually generated, as the funds that would have been spent at the movies or shopping mall, for example, have merely been redirected within the community.

Owners, teams, and leagues will almost always stretch the facts regarding what a new stadium could do for a city's economy. For example, the NFL estimated that the 2004 Super Bowl brought in more than $\$ 300$ million to the Houston area, whereas economists estimated that the number was closer to $\$ 65$ million. ${ }^{162}$

A study conducted and published in 2000 by the CATO Institute on the economic effects of professional sports facilities did not uncover a single instance in which there was a direct correlation between a professional sports stadium and a positive economic impact in the city. ${ }^{163}$ An example of a city that has not felt the promised benefits of a new stadium deal is

$156 I d$.

157 Id.

158 See generally Roger G. Noll \& Andrew Zimbalist, Sports, Jobs, And TAXes: The ECONOMIC IMPACT OF SpORTS TEAMS AND STADIUMS (Brookings Institution Press 1997) (includes a volume of articles derived from an October 1996 conference discussing how the economic effects of stadiums are generally much more minimal than often claimed).

$159 \mathrm{Id}$. at 80 .

160 Id. at 75

161 Id. at 80

162 Andrea Ahles, Impact of Marquee Events at Cowboys Stadium Questioned, FORT WORTH StAR-Telegram, Nov. 9, 2008.

163 See Miller Park: Economic Promises Got it Built. Has it Paid?, MilwaukeE J. Sentinel, Apr. 4, 2008, available at http://www.jsonline.com/sports/brewers/29508084.html. 
Milwaukee. ${ }^{164}$ Statistics show that since the city's professional baseball stadium opened in 2001, employment has declined by 5.4\% in Milwaukee County ${ }^{165}$ Furthermore, the employment rate at the hotels, where the surplus of visitors was supposed to stay, has dropped by $2.9 \%$, and retail trade employment has dropped by $9.9 \% .{ }^{166}$ Another city that never saw the promised benefits of a new stadium is Atlanta. ${ }^{167}$ The city invested in a new baseball stadium that opened in 1997 and brought in a total attendance of 3.46 million people in its first year. ${ }^{168}$ By the end of the second season in the stadium, attendance had dropped to 2.32 million, a staggering drop of 1.14 million total people from the previous year. ${ }^{169}$

Furthermore, it has been estimated that an NFL playoff game costs a city around $\$ 425,000$ in sales tax, possibly due to people spending less money at the stadium than they would out in the city, shopping and eating. ${ }^{170}$ A university economics professor and expert recently noted that the value of sporting events taking place in cities is typically much smaller than the hundreds of millions of dollars often stated. ${ }^{171}$ Example after example shows that cities never receive any of the promised benefits.

There is also much skepticism surrounding the idea of an increase in construction jobs that stem from the building of professional sports facilities. ${ }^{172}$ The construction workers who are put to work on stadium projects could very well be employed on other projects - the projects that the materials and supplies that go towards building a stadium could be used for, and which money that is given to a team (e.g., $\$ 1$ billion of tax exempt bonds given to the N.Y. Yankees by New York City) would better be spent on. Hence, a city such as New York that spends a great amount of money building stadiums incurs significant opportunity costs.

Thus, it is clear from the examples above that the taking of one's land for the construction of a sports stadium does not typically translate to a whole new prosperity within a community. If this is the case, why then do

167 Tim Tucker, Braves Enhance Park to Reverse Gate Decline, ATLANTA J. Const., Apr. 8, 2005, at E1.

168 Id.

169 Id.

170 Ahles, supra note 162.

171 Id.

172 See, e.g., David Nakamura, Goals Unmet on Stadium Construction Jobs For D.C. Workers, WASH. POST, Oct. 2, 2007, at B01. Local residents of Washington D.C. had only worked about one-third of the total hours of skilled labor needed to build a brand new stadium for Major League Baseball's Washington Nationals, despite the labor agreement's goal of $100 \%$ of the stadium jobs going to D.C. residents. 
governments continue to restrain individuals' property rights when the outcome leads to no significant benefit? Authors of a recent eminent domain study have warned that "[r]esearch has shown that without property rights, individuals will no longer face the incentive to make the best economic use of their property, be it a business or home, and economic growth will be limited. Potential residents and businesses may avoid communities that have a record of taking private property for economic development because of a greater uncertainty about losing their property to eminent domain." ${ }^{\prime 13}$

In sum, public subsidies collected to fund stadium projects reduce public spending on local infrastructure, as taxes are typically raised and money is drained out of education, public safety, and other areas in need of economic development. ${ }^{174}$ This is likely why there has never been any evidence proving that a sports stadium or arena built in a city will raise the level of real per capita personal income as is often promised by owners and city officials pushing for such a project. ${ }^{175}$ As Justice O'Connor pointed out in her Kelo dissent, "[ $\mathrm{t}$ ] he beneficiaries of [eminent domain] are likely to be those citizens with disproportionate influence and power in the political process, including large corporations and development firms." ${ }^{176}$

\section{RECENT AND CURRENT SPORTS FACILITY EMINENT DOMAIN CASES}

Bruce Ratner's Atlantic Yards Development Project, as one author points out, "is a perfect illustration - only one out of many recent eminent domain projects like it - of how little today's central planners have learned from a half century of failure." ${ }^{177}$ Ratner is the owner of the NBA's New Jersey Nets and the man who will be responsible for relocating 1,000 residents and workers in Brooklyn, New York if the largest private investment in Brooklyn's history is allowed to go through. ${ }^{178}$

In Goldstein v. Pataki, the trial court found that the principal public purpose of Ratner's $\$ 4$ billion project to build a stadium, along with residential and office space, was to eliminate blight, and therefore passed the "public use" requirement. ${ }^{179}$ The plaintiffs in Pataki were eleven owners

173 Report: Eminent Domain Could Hinder Development, supra note 143.

174 Dennis Coates \& Brad R. Humphreys, The Growth Effects of Sports Franchises, Stadia, and Arenas, 18 J. POL'Y ANALYSIS \& MGMT. 601, 622 (1999), available at http://onlinelibrary.wiley.com/doi/10.1002/(SICI)1520-6688(199923)18:4\%3C601::AID-PAM4\%3E3.0. $\mathrm{CO} ; 2-\mathrm{A} / \mathrm{pdf}$.

175 Id.

176 Kelo v. City of New London, 545 U.S. 469, 505 (2005).

177 See Gelinas, supra note 2.

178 Andy Newman, Guarding Their Homes Against the Bulldozer, N.Y. TiMES, Jan. 23, 2004, at B1.

179 Goldstein v. Pataki, 488 F. Supp. 2d 254 (E.D.N.Y. 2007). 
and renters of property on the land intended for use in the Atlantic Yards Arena and Development Project. Ratner petitioned the state and city to condemn the adjoining blocks to the proposed stadium for the construction of 6,000 high-rise apartments. The court used previous findings and stated that "a taking fails a public use requirement if and only if the uses offered to justify it are "palpably without reasonable foundation," such as if (1) the 'sole purpose' of the taking is to transfer property to a private party." "180 The plaintiffs failed to allege how having a professional sports franchise and new stadium would in itself not be a benefit to the public. ${ }^{181}$ The court also rejected the plaintiffs' allegations that the public use that would come from the condemnations are "mere pretexts" for wanting to "bestow a private benefit" on the development corporation, since that plan claimed that it would create large quantities of housing and office space, as well as a professional sports stadium, in an area that is mostly blighted. ${ }^{182}$

Similar to the homes that were taken by eminent domain in Kelo, the properties that Ratner wants the government to condemn are in no way "blighted." " The properties that would be taken include "two historic warehouses converted into fancy condos and sold at high prices just two years ago, a neighborhood bar that dates to pre-Prohibition days, and a flourishing arts-supply factory that employs two dozen legal immigrants and has recently opened a modest art gallery as well." ${ }^{184}$ The property that would be condemned is in an area that has been described as "the crossroad of three handsome neighborhoods where brownstones routinely sell for $\$ 1.5$ million, restaurants long ago went gourmet, and affordable housing disappears at an alarming rate." 185 According to one writer, [a] more ethically, economically and commercially driven crew would be hard to assemble, even in New York City. ${ }^{186}$ The three blocks that Ratner has selected for his project consist of artists, auto body shops, a world famous violin builder, a beloved neighborhood bar, and a hat company where ladies buy their hats for church.

Maybe the growth of this area is why Ratner has his eyes on this location for his project. Notice that he has not asked the government to condemn this land so that he could build luxury apartment buildings among the

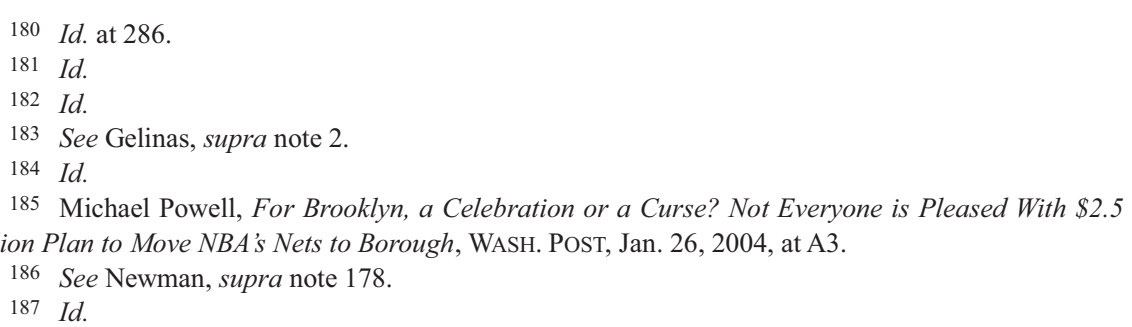


projects to bring upon economic development. ${ }^{188}$ A local print shop owner, whose store will be one of the properties condemned, is in disbelief, as he recently stated, "[f]or the greater public good, you must sacrifice your home. Okay. But for a sports arena we lose our homes. I'm in a state of shock." "189

The Court of Appeals for the Second Circuit affirmed the trial court's decision in Pataki, denying the plaintiffs' plea that 'the project's public benefits are serving as a 'pretext' that masks its actual raison d'etre: enriching the private individual [Ratner] who proposed it and stands to profit most from its completion." 190 The court deferred to past federal court decisions rather than deciding to grant the citizens of New York greater property security, even though Kelo suggested a state has the ability to do so. ${ }^{191}$ The majority stated that it cannot act contrary to the Midkiff standard, which is to say that it cannot disturb a determination of public use by elected officials. ${ }^{192}$ The plaintiffs' petition for writ of certiorari to the U.S. Supreme Court was denied, although Justice Alito obviously felt that the Kelo decision should be reexamined as he accompanied the denial with a statement that he would have granted the petition.

Another case that was recently heard in court involved the construction of the NFL's Dallas Cowboys' $\$ 1.1$ billion stadium, which is scheduled to open in Arlington in 2009. ${ }^{194}$ There were twenty-one eminent domain cases that challenged the condemnations taking place so that this facility could be built. ${ }^{195}$ In one of the cases, the plaintiffs, owners of seventeen the condemned parcels, claim that the project does not fall within eminent domain's permissible uses. ${ }^{196}$ According to the plaintiffs, the stadium plan is not a municipal project, as the city's contract gives complete and exclusive control of the stadium to the team. ${ }^{197}$ The attorney for the plaintiffs stated that "[ $\mathrm{t}]$ he city retains nothing of importance." 198 The city of Arlington claimed that the team is paying $\$ 2$ million per year in rent, committing to staying in the city for at least thirty years, and is going to bring upon great

$188 \mathrm{Id}$.

189 See Powell, supra note 185.

190 Goldstein v. Pataki, 516 F.3d 50, 52-53 (2d Cir. 2008).

191 Id. at 57.

192 Id. at 63-64.

193 Goldstein v. Pataki, 554 U.S. 930 (2008).

194 Jeff Mosier, Court Case Challenges Eminent Domain for Dallas Cowboys Stadium, DALLAS MORNING News, Sept. 10, 2008, available at http://www.dentonrc.com/sharedcontent/dws/dn/ latestnews/stories/091108dnmetstadium.616aec1e.html.

$\begin{array}{ll}195 & I d . \\ 196 & I d . \\ 197 & I d . \\ 198 & I d .\end{array}$ 
economic development in the surrounding areas. ${ }^{199}$ Threatened with the possibility of a delay in the opening of the stadium due to the multiple pending law suits, the city has now made moves to compensate the property owners a little more reasonably. In November, 2008, the city of Arlington settled with 13 of the property owners who brought claims, paying the owners a combined $\$ 5.8$ million, which is over five times more than Arlington's initial offer of $\$ 387,000 .^{200}$ The $\$ 387,000$ offer would have paid each of the property owners just $\$ 68,000$ per home. ${ }^{201}$

Perhaps the courts in the various states that are currently deciding on whether stadiums should be built in their cities should look at the recent court decision in City of Springfield v. Dreison Investments, Inc. ${ }^{202}$ in which a Massachusetts state court denied the use of eminent domain for the construction of a baseball stadium. ${ }^{203}$ The Springfield City Council had voted to use eminent domain to condemn three privately-owned parcels of land for what they referred to as "municipal purposes."204 It was recognized that the land selected for the condemnation was currently part of an urban renewal program, "in reasonably good condition," and likely to create public disfavor with any relocation costs associated with it. ${ }^{205}$ Despite these findings, Springfield's mayor approved the taking, and the City was to lease the condemned property to the Springfield Baseball Corporation that it would then use to build a new stadium for a minor league baseball team. ${ }^{206}$ However, the court held that "the primary beneficiary of the City's contribution to the project was not the public," as the primary purpose of the stadium was to allow a private corporation to own and operate it without giving the City a dime for rent. ${ }^{207}$

VII. ThE NEED FOR A BRIGHT-LINE Rule ON Public Use, AND THE NeCESSITY For HEIGHTENED SCRUTINY WHEN PRIVATE PROPERTY IS CONDEMNED AND GIVEN TO OTHER PRIVATE PARTIES

In 1795, Justice William Patterson cautioned:

199 Id.

200 Jeff Mosier, Arlington Settles Eminent Domain Cases Related to Dallas Cowboys Stadium, Dallas Morning News, Nov. 20, 2008, available at http://www.dallasnews.com/sharedcontent/ dws/news/localnews/stories/112108dnmeteminentdomain.1d103064a.html.

201 Joel Thomas, City to Pay Big After Cowboys Stadium Settlement, CBS 11 TV, Nov. 21, 2008.

202 City of Springfield v. Dreison Inv., No. 000014, 2000 WL 782971 (Mass. Feb. 25, 2000).

203 Id. at $* 152$

204 Id. at $* 1$.

205 Id. at $* 7$.

206 Id.

207 Id. at $* 141$ 
The Constitution is the origin and measure of legislative authority. It says to legislators, thus far ye shall go and no further. Not a particle of it should be shaken; not a pebble of it should be removed. Innovation is dangerous. One encroachment leads to another; precedent gives birth to precedent; what has been done may be done again; thus radical principles are generally broken in upon, and the Constitution is eventually destroyed. ${ }^{208}$

This statement should stand as a warning to courts that are faced in the future with the same type of eminent domain issue in Kelo. Because the majority in Kelo greatly broadened the government's eminent domain power while stripping individuals of property protections that the Founding Fathers believed in, there is now a need for a bright-line rule on what constitutes "public use," as well as "blight," and furthermore, courts should use a heightened level of judicial scrutiny when private property is condemned for the purpose of giving it to other private parties.

The major problem that the courts were faced with in the cases discussed above, and the main issue facing the courts today regarding issues of eminent domain, is how to interpret the phrase "public use."209 The issue arises because the Court over the years has developed various interpretations of the term. In one sense, the Court has defined "public use" as "barring government from taking an owner's property for the sole purpose of benefitting another private party. ${ }^{210}$ In other instances, the Court has held that a taking via the eminent domain power "to achieve any of a variety of broadly-defined public purposes can constitute a public use." "211 The Court at times has defined "public use" on its face, meaning that the new property must be for actual use by the public. ${ }^{212}$ This definition requires that the government actually own the property, and that it makes the property available to the general public to use and access. ${ }^{213}$ In contrast, courts have interpreted "public use" as synonymous with "public purpose," "making it irrelevant whether the government itself, or some other private party, ends up owning the property. ${ }^{214}$ It is these completely varying definitions of the phrase "public use" that has left the government's eminent domain power overly broad.

208 Vanhorne's Lessee v. Dorrance, 2 U.S. 304, 311-12 (1795).

209 Robert G. Dreher \& John D. Echeverria, Kelo's Unanswered Questions: The Policy Debate Over the Use of Eminent Domain for Economic Development, GEO. ENVTL. L. \& POL'Y INST. 3 (2000).

$210 I d$.

211 Id.

212 Id.

213 Id.

214 Id. 
As the government has grown and its power has expanded, so too, it seems, has the initially narrow interpretation of "public use." In 1789, the Supreme Court recognized that the public use clause of the Fifth Amendment was intended to limit the government's eminent domain power. ${ }^{215}$ Responding to the act of transferring an individual's private property to another private entity, the Court found that "[i]t is against all reason and justice, for a people to entrust a Legislature with SUCH powers; and, therefore, it cannot be presumed that they have done it." ${ }^{216}$ In its decision, the Kelo majority never created a test for determining what is and what is not a public use. $^{217}$ The idea generated from the Kelo decision - that private property can be taken away simply because another party believes it can generate more revenue from it - is a dangerous one that brings to question the safety of anyone's property. In her dissent, Justice O'Connor wrote:

Today the Court abandons this long-held, basic limitation on government power. Under the banner of economic development, all private property is now vulnerable to being taken and transferred to another private owner, so long as it might be upgraded - i.e., given to an owner who will use it in a way that the legislature deems more beneficial to the public - in the process. To reason, as the Court does, that the incidental public benefits resulting from the subsequent ordinary use of private property render economic development takings "for public use" is to wash out any distinction between private and public use of property - and thereby effectively to delete the words "for public use" from the Takings Clause of the Fifth Amendment. ${ }^{218}$

The Court's decision in Kelo will always allow for the government to condemn private property if it feels that a business can bring more economic stimulus to a neighborhood or city. The plaintiffs urged the Court that a line was needed, as "without a bright-line rule nothing would stop a city from transferring citizen A's property to citizen B for the sole reason that citizen $\mathrm{B}$ will put the property to a more productive use and thus pay more taxes." ${ }^{219}$ In essence, this is a serious threat to all private property owners since there will almost always be a business that can generate more income than another private individual. ${ }^{220}$ The Court, with its decision in

215 Calder v. Bull, 3 U.S. 386, 388 (1798).

216 Id.

217 See Kelo v. City of New London, 545 U.S. 469, 504 (2005).

218 Id. at 494 (O'Connor, J., dissenting).

219 Id. at 486-87 (majority opinion).

220 County of Wayne v. Hathcock, 471 Mich. 445, 482 (2004) ("Poletown's 'economic benefit' rationale would validate practically any exercise of the power of eminent domain on behalf of a private entity. After all, if one's ownership of private property is forever subject to the government's determina- 
Kelo, essentially made it possible for the government to justify any taking for a development plan of a private entity with the means to produce more money. Thus, it is crucial to the future of private property rights for there to be an established difference between public use and public purpose when it comes to making a determination of eminent domain constitutionality. Leaving the determination of what constitutes public use as opposed to private use solely to the political branches would, as Justice O'Connor opined, render the public use clause "little more than hortatory fluff.",221

At the same time, as the three dissenting justices in Kelo recommended, the Court must impose a "heightened" standard of judicial review for takings justified by economic development. ${ }^{222}$ These justices believe that "clear and convincing evidence" must be shown that the promised economic benefits of a plan will indeed occur. ${ }^{223}$ If strict scrutiny is used, then a government's taking of one's private property for the granting to another private party would only be allowed if there was a compelling purpose for the taking, and the taking was the least restrictive way to accomplish that purpose. Some may argue that the high strict scrutiny standard would be too much of a burden for the government to overcome when attempting to provide for the general welfare. However, these would be people who likely do not realize how wide open the door is for the eminent domain power to be utilized and abused. But by applying a strict scrutiny review, it will show there will be no question about whether the project, a sports stadium in this conversation, is vital to the public and cannot be completed by any other means than by condemning private land.

Even Justice Kennedy's concurrence in Kelo paves the way for a "heightened" review when he admitted that the Court's reasoning "does not foreclose the possibility that a more stringent standard of review than that announced in Berman and Midkiff might be appropriate for a more narrowly drawn category of takings." 224 He noted that a heightened standard maybe should be applied in order to prevent private transfers that are laced with "undetected impermissible favoritism of private parties.",25 This belief supports the idea that politicians and legislatures who support eminent domain and the public funding of stadiums may have ties to team owners or may have their own financial interests in mind when making eminent domain decisions.

\footnotetext{
tion that another private party would put one's land to better use, then the ownership of real property is perpetually threatened. ...")

221 Kelo, 545 U.S. at 497 (O’Connor, J., dissenting).

222 Id. at 477 (majority opinion).

223 Id. at 480.

224 Id. at 493 (Kennedy, J., concurring).

225 Id.
} 
The situation in Kelo was quite different than the situations in the previous cases of Berman and Midkiff, where the government's power of eminent domain was enforced in an effort to curb social ills in the community brought on by blight and inequitable land oligopolies. ${ }^{226}$ Justice O'Connor, who wrote the opinion in Midkiff supporting the condemnation, yet dissented in Kelo, differentiated the two cases in that the neighborhood deemed to be blighted in Berman was made up of mostly properties that "were beyond repair."227 This description of how the area was at the time of the taking depicts a situation that caused harmful conditions to the general public that the redevelopment plan had the main purpose of curing. ${ }^{228}$ Such was not the case in Kelo, where the homes condemned were not blighted, and the residents of the town were not in despair that required condemnation of land by government in order to protect the health, safety, and general welfare of the public citizens. Furthermore, Justice Kennedy, in his concurrence discussing the situation in Kelo, made three points that are easily distinguishable from any eminent domain stadium construction project:

1. This taking occurred in the context of a comprehensive development plan meant to address a serious city wide depression, and the projected economic benefits of the project cannot be characterized as de minimis;

2. The identities of most of the private beneficiaries were unknown at the time the city formulated its plans; and

3. The city complied with elaborate procedural requirements that facilitate review of the record and inquiry into the city's purposes. ${ }^{229}$

In response to point one made by Justice Kennedy, many takings that have occurred for stadium projects were done so in areas that do not consist of a "city wide depression." "230 Furthermore, it would never be the case where the identities of the private beneficiaries would be unknown at the time of a taking for a stadium, as it will always be a professional sports team and its owner. Finally, it is likely impossible to determine a city's purpose when it pushes for a new stadium, as the intentions of politicians and legislative parties could be for a variety of reasons not imperative to the public.

A proper test for determining when a public use exists to allow a legal eminent domain exercise may come from Hathcock. Using this three-part

\footnotetext{
226 See Berman v. Parker, 348 U.S. 26 (1954); Haw. Hous. Auth. v. Midkiff, 467 U.S. 229 (1984).

227 Kelo, 545 U.S. at 498 (O’Connor, J., dissenting).

$228 I d$. at 480 (majority opinion).

229 Id. at 493 (Kennedy, J., concurring).

230 See, e.g., Atlantic Yards Project, supra note 144.
} 
test allows the government to strike a proper balance between its eminent domain power and the right of individuals to be secure from the taking of their private property. Thus, first the government could see if the transaction involved is a "public necessity of the extreme sort otherwise impracticable." "231 These are transactions that could not be accomplished if not for government acquisition. Second, government would use eminent domain to transfer property to a private entity, if that private entity is to remain "accountable to the public in its use of that property." 32 Finally, the government under this Hathcock three-part test would be able to use eminent domain if the "selection of the land to be condemned is itself based on public concern." "233 Under this test, a "public use" can be more clearly distinguished, and the use of eminent domain to clear the way for a stadium will likely never pass.

Easier and less costly methods exist for the government to orchestrate an urban redevelopment in hopes of boosting a weak economy. ${ }^{234}$ These options include tax policies, enterprise zones, small business loans, landscaping and urban design improvements, and the alteration of permits. ${ }^{235}$

\section{ARE SPORTS FACILITIES A PUBLIC USE?}

Is a football stadium, accessible only to those individuals willing to pay expensive ticket prices, really a "public use?" The concept of using public funds to construct a stadium goes back to the 1930s. In 1930, the Court of Appeals of Ohio was faced with the issue of whether public funds could be the main source of financing for the building of a stadium in Cleveland. $^{236}$ The Ohio court ruled in favor of public funding for the stadi$\mathrm{um}^{237}$ in what began a trend that many cities and states are still debating today. In its rationale of determining that a sports stadium serves a public purpose, the court pointed out that both the Greek and Roman empires constructed and maintained stadiums. ${ }^{238}$ Yet, it is a difficult to see a comparison between these historical empires (which, it must be noted, eventually collapsed) and today's greedy sports team owners and players with lucrative contracts who are the main beneficiaries.

\footnotetext{
231 County of Wayne v. Hathcock, 471 Mich. 445, 473 (2004).

232 Id. at 474 .

233 Id. at 475.

234 Erik Kancler, This Land is Our Land: What Eminent Domain is Nothing to Fear - so Long as its Abuses Can be Curbed, Mother JONES, Mar. 18, 2005, available at http://motherjones.com/politics/2005/03/land-our-land.

235 Id.

236 Meyer v. City of Cleveland, 171 N.E. 606 (Ohio Ct. App. 1930).

237 Id.

238 Id. at 607
} 
Because professional sports teams are popular throughout the country and garner a lot of attention, many states have legislation that allows professional sports facilities to be considered a public use and provide wide latitude for use of eminent domain to construct sports stadiums and arenas. ${ }^{239}$ Without a bright-line rule, courts cannot clearly distinguish the public use that derives from stadiums from other privately-owned entertainment venues, such as movie theaters and theme parks. ${ }^{240}$ These quasipublic properties, such as theaters, amusement parks, and hotels, have traditionally been viewed as venues for which the government cannot exercise its eminent domain power. ${ }^{241}$

Further, if the government takes property that will serve both public and private uses, it will be an invalid exercise of its eminent domain power if the private use cannot be overlooked and the uses are commingled to the extent that they cannot be separated. ${ }^{242}$ In other words, the court must strike down the government's use of eminent domain if the stated public purpose, which in most stadium cases is to improve the economic situation of a city, is only incidental to the benefits that will be confined on the private parties involved with the development plan. ${ }^{243}$

As mentioned in the above section discussing the history of eminent domain, the land that was taken through eminent domain traditionally had to be equally accessible to the public. How is it then that the definition of "public use" has become so broad as to include sports stadiums and arenas where customers are charged gross amounts of money to attend? A team cannot claim that its facility serves a recreational public use such as a park when one has to dig deep in his pockets in order to step foot onto the property.

Finally, besides the owners and teams, politicians are benefitting greatly as well, despite the fact that eminent domain powers are not bringing the promised benefits, as "private assets are forced into the public sphere for political redistribution." ${ }^{244}$ One author has pointed out that giving such a broad eminent domain power to legislatures that get political donations from corporate America (such as Pfizer, in the case of Kelo) is not a great strategy. ${ }^{245}$ Further, with no strict restrictions placed on what is deemed a public use, "politicians have figured out that eminent domain is an easy way for them to take land away from people who aren't making

239 Dreher \& Echeverria, supra note 209.

240 Id. at 41.

241 Julius L. SACKMAN, Nichols ON EMINENT DOMAIN § 7.03(1).

242 Id. $\S 7.03(5)(\mathrm{d})$.

243 Kelo v. City of New London, 545 U.S. 469, 491 (2005) (Kennedy, J., concurring).

244 Gelinas, supra note 2.

245 See Epstein, supra note 103, at 359. 
very good use of it - because they don't pay a lot in taxes - and hand it over to others who will make "better" use of it - because they will be subject to much higher taxation." ${ }^{246}$ Often times, politicians pushing for the construction of a new stadium try to sway others to their side to the extent that it feels as if they believe that this project would be the only conceivable way of revitalizing a city. ${ }^{247}$ Believing that some politicians may have their own interests in mind when it comes to a project they deem necessary to enforce eminent domain for, Chip Mellor, the president of the Institute for Justice and an advocate eminent domain reform nationwide, recently stated that "[p]erhaps it is time for government officials to take an oath like doctors and promise to "first, do no harm."'

Agreeing with the idea that eminent domain is quite often used by powerful politicians to exploit those who are politically disempowered for financial gain, Justice Thomas pointed out in his Kelo dissent the destructive consequences that eminent domain has had upon those with which the power was abused. ${ }^{249}$ In fact, very few legislative policies exist that have done more to destroy minority communities. ${ }^{250}$ Most of the estimated three to four million individuals who have been forcibly displaced from their private properties as a result of "urban renewal" takings since World War II have been minorities. ${ }^{251}$ Now, after Kelo, minority communities will continue to be stripped of their homes and opportunities as many feel that this decision just affirms the government's permission to take and redistribute land from the poor to wealthy commercial interests. ${ }^{252}$ As long as the power of eminent domain remains such an easy and cheap maneuver, politicians will continue to make use of it at the public's expense.

246 George C. Leef, An End to Eminent Domain Abuse?, FreEdom DaILY, June 24, 2005, http://www.fff.org/freedom/fd0504d.asp.

247 Id.

248 Report: Eminent Domain Could Hinder Development, supra note 143.

249 Lopez, supra note 114, at 594-95.

250 David Beito \& Ilya Somin, Battle Over Eminent Domain is Another Civil Rights Issue, Kan. CITY STAR, Apr. 27, 2008, available at http://www.cato.org/pub_display.php?pub_id=9361.

251 Id. (An example of such a taking against a minority community was in 2004 , when the city Alabaster, Alabama condemned 400 acres of rural property, which was mostly owned by low-income African Americans, in order to build a new Wal-Mart. Note: Two other Wal-Marts already existed within a fifteen mile radius.).

252 Id. (The National Association for the Advancement of Colored People filed an amicus brief in Kelo stating that " $[\mathrm{t}]$ he burden of eminent domain has and will continue to fall disproportionately upon racial and ethnic minorities, the elderly, and economically disadvantaged." The eminent domain power, according to the NAACP, is a "license for government to coerce individuals on behalf society's strongest interests."). 


\section{CONCLUSION}

Now, take a moment and imagine once again the scenario laid out in the introduction of this article. Five years have passed, you are now living in a different neighborhood, and the city that you were forced to leave when your home was taken from you is worse off than had it been at the time the government came in to claim it. This is a reality, as the promises of economic benefits of the newly built stadium that replaced your home fail to materialize. $^{253}$ There is no compensation great enough to make up for the fact that your home was taken away from you with no reliable justification.

As Justice Thomas stated in his Kelo dissent, "[s]o-called "urban renewal' programs provide some compensation for the properties they take, but no compensation is possible for the subjective value of these lands to the individuals displaced and the indignity inflicted by uprooting them from their homes."254 A study conducted shortly after the Kelo decision was announced showed that "protecting private property rights" was the number one legal issue that concerned the public now that this case had made the government's power of eminent domain look so effortless. ${ }^{255}$

Sports team owners have long lobbied for eminent domain as a way to acquire property in order to finance a multimillion dollar facility for their teams to play in, without having to dig deep into their own pockets. Eminent domain is a crucial power that the government possesses, and without it, redevelopment efforts in truly poverty-stricken cities could possibly strike a deadly blow to urban revival in these places. However, without a definite rule of what constitutes public use and an acknowledgement that public use is not the same thing as public purpose, private property owners are left in a dangerous position of never knowing when their homes or businesses may potentially be taken away from them. Where the federal laws have failed property owners already, it is up to state legislators to make proper adjustments to their own constitutions to protect the

253 Gelinas, supra note 2. "New Haven officials used eminent domain to raze block after block of immigrant and working-class communities to build 'Modernist' office complexes, industrial buildings, and housing projects, as well as a strip mall, a parking garage, and connections to highways," in an effort to cure housing problems and revitalize the economy; however over the next twenty-five years, New Haven's population declined by thirty percent and its poverty increased. Id. Professor Douglas Rae, of Yale University, believes that New Haven's poverty level would be lower today without the urban development plan, as it "destroyed a lot of economic and social vitality." $I d$. The city of Boston used its power of eminent domain to condemn twenty properties from private owners to build a $\$ 800$ million convention center, with the promises of improving the local economy; however, the "center sits idle most of the time" and "[f]irst year bookings and attendance were only one-sixth of what the city projected." Malanga, supra note 145, at B13.

254 Kelo v. City of New London, 545 U.S. 469, 521 (2005) (Thomas, J., dissenting).

255 See Lopez, supra note 114, at 595. 
individuals residing within their borders. The Court should further apply a heightened level of scrutiny, as the right to be secure in one's property is an essential foundation upon which the country's Founding Fathers based the Declaration of Independence. With the decision in Kelo, the Court confirmed the ease with which the government can condemn land from private property owners. Under the rational basis review that was utilized by the majority, it is difficult to imagine any development plan that would fail the "public use" test. Furthermore, the fact that courts need not make a factual determination that a proposed plan will meet any of its projected goals seems like an extremely low threshold to take someone's private property.

Even Justice Stevens, who wrote the decision in Kelo declaring that the power of eminent domain was constitutional for economic development, recently said in a speech that he would oppose using eminent domain if he was a state or local legislator." "My own view is that the free play of market forces is more likely to produce acceptable results in the long run than the best-intentioned plans of local officials," Stevens asserted. ${ }^{257}$

The Director of Environmental and Regulatory Affairs for the National Center for Public Policy Research understands the dangers that arise from the Court's current view of eminent domain. ${ }^{258}$ In a quote that sums up the value individuals throughout the U.S. place on property and the danger that these individuals are susceptible to, the Director recently stated that "[O]ne man's blight is another man's castle. Without proper restrictions and welldefined parameters, governments will exploit the blight loophole and continue to abuse eminent domain power." 259 Unfortunately, the blight loophole has already affected so many. For those individuals who have "taken one for the team" so that a professional sports team could play in the location where their property once stood, it is both the owners of these teams, as well as the government, who have taken advantage of a power that apparently is no longer governed by the U.S. Constitution.

256 See Gelinas, supra note 2.

257 Id.

258 See The National Center for Public Policy Research, Government Playing with 'Corked Bat' in Stadium Game - National Center Cites Need for Eminent Domain Reform, Oct. 18, 2005, http://www.nationalcenter.org/PREminentDomainAbuse1005.html. 